\title{
ANALISIS WACANA KRITIS DALAM KUMPULAN PIDATO PRESIDEN REPUBLIK INDONESIA KE-7 Ir. JOKO WIDODO
}

\author{
Muhammad Syawaludin
}

\begin{abstract}
Abstrak - Tujuan penelitian ini adalah untuk mendeskripsikan dan memahami bagaimanakah Analisis Wacana Kritis untuk mengungkapkan pemaknaan Pidato Presiden Republik Indonesia melalui elemen-elemen pada struktur makro, superstruktur, dan struktur mikro. Penelitian ini merupakan penelitian deskriptif kualitatif dengan menggunakan metode analisis wacana kritis model Teun A. Van Djik. Data dikumpulkan dengan cara dokumentasi, kemudian dicatat dalam kertas kerja berdasarkan struktur makro, superstruktur, dan struktur mikro. Beberapa simpulan dari penelitian ini adalah; Pertama ditemukan makana ideologi kerakyatan, ideologi sosialisme, dan ideologi nasionalisme terhadap kumpulan pidato Presiden Republik Indonesia ke-7. Kedua, strategi yang digunakan Presiden Republik Indonesia untuk menyembunyikan pemaknaan pada ideologi kerakyatan, ideologi sosialisme, dan ideologi nasionalisme adalah melalui elemen-elemen pada struktur makro, superstruktur, dan struktur mikro. Makna ideologi kerakyatan ditunjukkan dengan menguraikan kalimat yang bernada gemilang, maju, sejahtera, aman dan tentram. Selain itu makna ideologi sosialisme ditunjukkan dengan menguraikan kalimat yang bermakna menghargai dan menghormati.
\end{abstract}

\section{Kata Kunci-Analisis Wacana Kritis, Pidato Presiden, Teun A Van Djik}

Abstract - The purpose of this study is to describe and understand how Critical Discourse Analysis is to reveal the meaning of the President's Speech of the Republic of Indonesia through elements in the macro structure, superstructure, and micro structure. This research is a qualitative descriptive study using the critical discourse analysis method of the Teun A. Van Djik model. Data is collected by means of documentation, then recorded in working papers based on macro structure, superstructure, and micro structure. Some conclusions from this study are; First was found the populist ideology, socialism ideology, and nationalism ideology of the 7th President of the Republic of Indonesia speeches. Second, the strategy used by the President of the Republic of Indonesia to hide the meaning of popular ideology, socialism ideology, and nationalism ideology is through elements in the macro structure, superstructure, and micro structure. The meaning of popular ideology is shown by describing sentences that are brilliant, forward, prosperous, safe and secure. In addition, the meaning of the ideology of socialism is shown by elaborating on sentences that mean respect and respect.

Keywords_-Critical Discourse Analysis, President's Speech, Teun A Van

\section{PENDAHULUAN}

Wacana sering digunakan dalam berbagai acara, seperti seminar, pelatihan, atau pengajian agama. Wacana juga sering dijumpai dan dituliskan dalam berbagai artikel, makalah, maupun buku. Hal ini menunjukkan bahwa istilah wacana sudah menjadi konsumen pelbagai lapisan masyarakat, mereka menggunakannya dengan arti yang tepat. Sebaliknya, ada juga yang menggunakannya secara tidak tepat. Jorgensen dan Louise dikutip Djajasudarma (2010:1) mengemukakan bahwa penggunaan kata "wacana" adalah gagasan umum bahwa bahasa ditata menurut pola-pola yang berbeda yang diikuti oleh ujaran para 
pengguna bahasa ketika mereka ambil bagian dalam domain-domain kehidupan sosial yang berbeda, misalnya dalam domain "wacana medis" dan "wacana politik".

Berdasarkan uraian di atas, maka peneliti perlu melakukan analisis wacana kritis secara utuh, baik analisis terhadap struktur makro, superstruktur, dan struktur mikro yang terdapat dalam naskah pidato Presiden Republik Indonesia Ir. Joko Widodo. Selain itu, peneliti perlu mengetahui strategi dari penulis naskah pidato dalam menempatkan pemaknaan dan maksud tersembunyi mengenai keberpihakan maupun ketidak berpihakannya terhadap pemerintah dan objek tulisan.

Berdasarkan latar belakang di atas, maka masalah dalam penelitian dapat diidentifikasi sebagai berikut:

1. Bagaimanakah analisis wacana kritis Pidato Presiden Republik Indonesia Ir. Joko Widodo?

2. Bagaimanakah tema/topik yang dikedepankan pada Pidato Presiden Republik Indonesia Ir. Joko Widodo?

3. Bagaimanakah pesan-pesan tersembunyi yang terdapat pada Pidato Presiden Republik Indonesia Ir. Joko Widodo?

4. Apa sajakah ideologi yang tersembunyi yang ingin disampaikan oleh Presiden Republik Indonesia dalam pidato?

5. Bagaimanakah strategi Presiden Republik Indonesia Ir. Joko Widodo pada kumpulan pidatonya dalam menyembunyikan makna berdasarkan struktur makro?

6. Bagaimanakah strategi Presiden Republik Indonesia Ir. Joko Widodo pada kumpulan pidatonya dalam menyembunyikan makna berdasarkan superstruktur?

7. Bagaimanakah strategi Presiden Republik Indonesia Ir. Joko Widodo pada kumpulan pidatonya dalam menyembunyikan makna berdasarkan struktur mikro?

Masalah dalam penelitian ini dapat dirumuskan sebagai berikut:

1. Bagaimanakah strategi Presiden Republik Indonesia Ir. Joko Widodo dalam menyembunyikan makna berdasarkan struktur makro, superstruktur, dan struktur mikro pada kumpulan pidatonya?

2. Apa sajakah ideologi yang tersembunyi yang ingin disampaikan oleh Presiden Republik Indonesia dalam kumpulan pidatonya?

Penelitian ini diharapkan dapat bermanfaat bagi mahasiswa, masyarakat/pembaca dan peneliti sebagai berikut,

1. Bagi mahasiswa, secara praktis dapat dijadikan bahan tambahan dalam menganalisis wacana pidato secara kritis;

2. Bagi masyarakat/pembaca, diharapkan dapat bermanfaat bagi pembaca untuk mendapatkan informasi dan pemahaman yang utuh mengenai isi 
pidato analisis wacana kritis pidato Presiden republik Indonesia Ir. Joko Widodo;

3. Bagi peneliti, penelitian ini diharapkan dapat meningkatkan pengetahuan dan wawasan khususnya tentang analisis wacana kritis dan agar ditindak lanjuti untuk melakukan penelitian analisis wacana kritis terhadap pidato-pidato dengan lebih mendalam dan ruang lingkup yang lebih luas.

\section{Analisis Wacana Kritis}

Analisis wacana dalam paradigma kritis merupakan suatu upaya untuk melihat secara dekat tentang bagaimana makna pesan suatu wacana diorganisasikan, digunakan, dan dipahami. Analisis wacana, dalam kajiannya tidak semata-mata dipahami sebagai studi bahasa. Analisis wacana dalam paradigma kritis memang menggunakan bahasa dalam teks yang dianalisis, tetapi kajian bahasa dalam analisis wacana kritis berbeda dengan kajian bahasa dalam linguistik tradisional. Bahasa yang dianalisis dalam analisis wacana kritis bukan hanya menggambarkan aspek bahasa saja, tetapi menghubungkannya dengan konteks. Konteks dalam hal ini berarti bahasa dipakai untuk tujuan tertentu termasuk di dalamnya untuk tujuan praktik kekuasaan.

Analisis wacana kritis merupakan analisis wacana yang bersifat "kritis" maksudnya adalah bahwa analisis ini bertujuan mengungkap peran praktik kewacanaan dalam upaya melestarikan dunia sosial, termasuk hubungan-hubungan sosial yang melibatkan hubungan kekuasaan yang tak sepadan. Oleh sebab itu, salah satu tujuannya adalah agar bisa memberi kontribusi kepada perubahan sosial disepanjang garis hubungan kekuasaan dalam proses komunikasi dan masyarakat secara umum.

Van Dijk (2001:352) menyatakan bahwa "Critical discourse analysis (CDA) is a type of discourse analytical research that primarly studies the way social power abuse, dominance, and inequality are enacted, reproduced, and resisted by text and talk in the social and political context. Jadi AWK adalah suatu jenis penelitian analisis wacana yang menitikberatkan kepada kajian bagaimana penyalahgunaan kekuasaan, dominasi, dan ketidaksetaraan dibuat, diproduksi, dan ditolak melalui teks atau lisan di dalam konteks sosial dan politik.

Berdasarkan hal di atas, maka dirumuskanlah suatu pengertian analisis wacana yang bersifat kritis yaitu suatu pengkajian secara mendalam yang berusaha mengungkap kegiatan, pandangan, dan identitas berdasarkan bahasa yang digunakan dalam wacana.

\section{METODOLOGI PENELITIAN}

\section{Tujuan Penelitian}


Tujuan penelitian ini untuk mendeskripsikan:

1. Strategi Presiden Republik Indonesia Ir. Joko Widodo dalam menyembunyikan makna berdasarkan struktur makro, superstruktur, dan struktur mikro pada kumpulan pidatonya.

2. Ideologi yang tersembunyi yang ingin disampaikan oleh Presiden Republik Indonesia dalam kumpulan pidatonya.

\section{Metode Penelitian}

Penelitian ini menggunakan metode deskriptif kualitatif. Hal ini tidak lepas dari tujuan penelitian kualitatif. Ingin mendeskripsikan fakta dan mencari makna secara holistik dengan perspektif. Metode penelitian kualitatif adalah metode yang lebih menekankan pada makna dari pada generalisasi. Metode penelitian ini menngunakan analisis data yang dilakukan bersifat induktif berdasarkan fakta-fakta yang ditemukan di lapangan. Jadi metode kualitatif adalah metode yang digunakan untuk mendapatkan data yang mendalam, suatu data yang mengandung makna (Sugiyono, 2012:15). Melalui metode ini peneliti menganalisis lima wacana teks pidato Presiden Republik Indonesia Ke-7 Ir. Joko Widodo untuk membongkar strategi dibalik penulisan yang terdapat di dalam lima teks pidato Presiden Republik Indonesia Ke-7 Ir. Joko Widodo serta dapat mendeskripsikan ideologi makna yang ada pada lima teks

pidato Presiden Republik Indonesia Ke-7 Ir. Joko widodo.

\section{Teknik Pengumpulan Data}

Teknik pengumpulan data dalam penelitian ini adalah teknik dokumentasi. Teknik dokumentasi adalah teknik yang digunakan untuk mencari data mengenai halhal (variabel) yang bersumber pada tulisan yang menyelidiki benda-benda tertentu seperti buku-buku, majalah, dokumen, peraturan-peraturan, notulen rapat, catatan, dan sebagainya (Arikunto, 2006:158). Dokumen dalam penelitian ini adalah naskah pidato presiden Republik Indonesia Ir. Joko Widodo.

\section{Teknik Analisis Data}

Teknik yang digunakan untuk menganalisis data dalam penelitian ini adalah teknik analisis isi. Menurut Badara (2012:63), analisis isi atau analisis konten digunakan untuk memahami pesan simbolik dari suatu wacana atau teks, yang dimaksud pesan simbolik tersebut berupa tema atau ide-ide pokok sebuah teks sebagi isi utama dan konteks sebagi isi laten (pesan yang tersembunyi).

Dalam penelitian ini, pesan simbolik tersebut berupa tema atau ide-ide pokok dalam naskah pidato presiden Republik Indoneia Ir. Joko Widodo dan yang dimaksud dengan konteks ialah aspek sosial, budaya, ekonomi, politik yang mempengaruhi terbentuknya naskah pidato presiden Republik Indonesia Ir. Joko Widodo. 
HASIL PENELITIAN

Temuan Hasil Penelitian

Strategi Presiden Republik Indonesia Ir. Joko Widodo Menyembunyikan Makna dalam Pidato

\section{a. Struktur Makro}

Sebuah teks wacana apabila diteliti strukturnya, maka di dalamnya akan terdapat struktur makro, superstruktur, dan struktur mikro. Bagian terbesar dari wacana atau yang meliputi kerangka besarnya adalah elemen tematik atau topik.

Topik (bahasa Yunani: topi) adalah inti utama dari seluruh isi tulisan yang hendak disampaikan. Topik merupakan hal yang ditentukan pertama kali saat penulis akan membuat tulisan. Topik awal tersebut kemudian dikembangkan menjadi sebuah tulisan. Kalimat topik adalah kalimat yang paling terpenting dalam sebuah paragraf karena merupakan ide utama dalam paragraf tersebut. Topik juga mengontrol dan membatasi ide yang didiskusikan dalam paragraf. Kalimat topik dibagi menjadi dua bagian yaitu topik dan pengontrol ide, sedangkan topik adalah subjek yang kita bicarakan.

Tema (bahasa Yunani: thithenai) adalah sesuatu yang menjadi pokok masalah dalam cerita yang telah diuraikan. Tema menyiratkan amanat atau tujuan yang ingin disampaikan. Tema merupakan suatu gagasan pokok atau ide pikiran dalam membuat suatu tulisan. Dalam setiap tulisan tentunya mempunyai sebuah tema karena dalam sebuah penulisan dianjurkan harus memikirkan tema apa yang akan dibuat. Tema inilah yang akan menentukan arah tulisan atau tujuan dari suatu tulisan. Menentukan tema berarti menentukan apa masalah sebenarnya yang akan diuraikan.

Apa yang ingin diungkapkan komunikator dalam isi pesannya terungkap dalam topik. Topik juga menunjukkan konsep dominan, sentral, dan paling penting dari isi suatu berita. Oleh karena itu, sering juga disebut tema/topik.

\section{Pembahasan terhadap Temuan Penelitian}

1. Strategi Presiden Republik Indonesia Ir. Joko Widodo Menyembunyikan Makna dalam Pidato

\section{a. Struktur Makro}

Struktur makro wacana terdiri dari elemen tematik atau topik. Inti utama dari seluruh isi teks wacana disebut juga dengan topik atau tema. Topik merupakan hal yang ditentukan pertama kali saat membuat tulisan. Bertititk tolak dari topik awal tersebut kemudian dikenbangkan menjadi sebuah tulisan.

Pokok masalah dalam teks pidato yang telah diuraikan disebut juga dengan istilah tema. Tema menyiratkan pesan atau tujuan yang ingin disampaikan. Tema inilah yang akan menentukan arah tulisan atau tujuan dari suatu tulisan. Masalah sebenarnya yang akan diuraikan ditentukan oleh tema apa yang akan dikembangkan. 
Hal-hal pokok yang ingin diungkapkan Presiden Republik Indonesia dalam isi pesannya terungkap dalam topik. Topik juga menunjukkan konsep dominan, sentral, dan paling penting dari isi suatu teks pidato, oleh karena itu sering juga disebut tema atau topik.

Gambaran umum dari suatu teks wacana dapat tergambar dari elemen tematik. Tema atau topik disebut sebagai gagasan inti, ringkasan atau yang utama dari suatu teks.

Tema yang terdapat dalam pidato Presiden Republik Indonesia pada tanggal 16 Agustus 2017 tentang "Pidato Kenegaraan HUT Ke-72 Proklamasi Kemerdekaan Indonesia" adalah meningkatkan kualitas pembangunan manusia dalam mengantisipasi perubahan dunia yang sangat cepat dan digital mulai dari pembangunan sumber daya manusia akan terus berlanjut. Pemerintah bukan hanya konsentrasi untuk mengurangi dampak kekurangan gizi kronis, menekan angka stunting, tapi juga menyiapkan generasi muda yang berkualitas, yang terampil dan siap untuk berkompetisi. Untuk itu, Pemerintah menginisiasi peningkatan kompetensi tenaga kerja, antara lain melalui pendidikan dan pelatihan vokasi. Kita terus memperbanyak dan memperkuat pendidikan SMK dan Politeknik yang harus memiliki keterkaitan dengan dunia industri. Semuanya dilakukan untuk menyiapkan sumber daya manusia yang handal dan tangguh.
Pada tanggal 16 Agustus 2017 Presiden Republik Indonesia berpidato dengan judul "Kenegaraan di Sidang MPR Tahun 2017" mengenai tema "Meningkatkan pemerataan pembangunan dibidang ideologi, politik, ekonomi, sosial budaya, pertahanan dan keamanan". Dari tema ini, Presiden Republik Indonesia menceritakan tentang pemerataan ekonomi yang berkeadilan sehingga dapat meningkatan pembangunan yang merata untuk mempersatukan Indonesia. Tidak hanya pemerataan ekonomi tapi juga dalam pembangunan ideologi, politik, sosial dan budaya. Dalam bidang ideologi, memperkuat konsensus kebangsaan untuk menjaga Pancasila, UUD 1945, NKRI dan Bhinneka Tunggal Ika. Pembangunan sosial dan kebudayaan yang menitik beratkan pada generasi penerus bangsa untuk cinta terhadap tanah airnya, memiliki etika, budi pekerti dan sopan santun, mempunyai karakter yang kuat dan tangguh.

Tema yang disampaikan Presiden Republik Indonesia pada tanggal 16 Agustus 2018 dengan judul "Pidato Kenegaraan HUT Ke-73 Proklamasi Kemerdekaan Indonesia" mengenai tema perkembangan dan pertumbuhan negara Indonesia di dalam bidang politik, ekonomi, infrastruktur, pendidikan dan hubungan luar negeri yang bertujuan untuk mencapai kesejahteraan dan kemakmuran bagi masyarakat Indonesia. Dalam pidato tersebut menyampaikan peranan yang besar terhadap sumber daya 
manusia. Pembangunan dalam bidnag pendidikan sebagai prioritas pembangunan, hal ini setidaknya dapat diwujudkan melalui pemberian dukungan bagi tersedianya sarana, prasarana dan adana yang memadaisehingga pelayanan pendidikan pada masyarakat dilaksanakan secara merata, relevan, efisien, dan efektif.

Tema yang disampaikan pada tanggal 16 Agustus 2018 oleh Presiden Rebuplik Indonesia adalah mengembangkan proses dalam mencapai kesejahteraan bangsa dengan cara membangun infrastruktur, jaminan kesehatan, pendidikan, dan membuat peraturan hukum yang tegas beserta sanksinya. Presiden Rebuplik Indonesia menyampaikan pembangunan dibidang pendiidkan tidak pernah berakhir atau selesai, semakin maju perkembangan dunia maka semakin dituntut manusia yang berkualitas, beriman dan bertaqwa sehingga pendiidkan harus ditingkatakan sesuai dengan tuntutan dan kebutuhan pembangunan nasional di masa -masa yang akan datang, dengan seperti itu dapat membuka lapangan pekerjaan baru dan menyerap pengangguran.

Pada pidato Presiden Republik Indonesia yang berjudul Pidato Sambutan Penutupan Asian Games 2018 di Hadapan Atlet pada tanggal 2 September 2018 mengangkat tema memberikan apresiasi atas prestasi para atlet dan orang-orang yang ikut serta dalam penyelenggaraan Asian
Games XVIII Tahun 2018 di Jakarta dan Palembang, Indonesia. Dari tema ini Presiden Republik Indonesia mengucapkan terimakasih kepada para atlet dan oarang yang ikut serta dalam penyelengaraan Asian Games yang telah bekerja keras untuk memperoleh medali atau kejuaraan sehingga membuat Indonesia bangga akan prestasi yang diraih.

\section{b. Superstruktur}

Teks wacana pada umumnya mempunyai superstruktur yang berupa skema atau alur dari pendahuluan sampai akhir. Alur tersebut menunjukkan bagaimna bagianbagian dalam teks disusun dan diurutkan sehingga membentuk kesatuan arti.

Skematik terdiri dari dua elemen yaitu Summary yang ditandai dnegan elemen judul, elemen skema ini merupakan elemen yang dipandnag penting dan Lead umumnya sebagai pengantar ringkasan apa yang ingin dikatakan sebelum masuk dalam naskah teks secra lengkap. Selain judul dan lead dalam skematik terdapat elemen Story yakni cerita secra keseluruhan, proses atau jalannya peristiwa.

1) Lead

Lead umumnya sebagai pengantar ringkasan apa yang ingin dikatakan sebelum masuk dalam isi teks pidato secara lengkap. Lead pidato dimulai dengan nama dan menyebut judul pidato. Selanjutnya, mulai dengan kutipan langsung dan menjelaskan 
dengan ringkasan pokok masalah. Setelah itu, mulai dengan peristiwa atau keadaannya.

$$
\text { Lead dalam pidato Presiden }
$$

Republik Indonesia yang berjudul

"Kenegaraan HUT Ke-72 Proklamasi

Kemerdekaan Indonesia Jakarta, 16 Agustus

2017" dimulai dengan nama yaitu "Yang saya hormati, Ketua, para Wakil Ketua, dan para Anggota Dewan Perwakilan Daerah Republik Indonesia.

\section{2) Story}

Story yakni naskah teks secara keseluruhan, proses atau jalannya peristiwa, mengenai episode atau kisah utama dari peristiwa tersebut. Komentar yang ditampilkan dalam teks, menggambarkan bagaimana pihak-pihak yang terlibat memberikan komentar atau suatu peristiwa.

\section{Elemen story yang terdapat Detail}

Elemen ini berhubungan dengan informasi yang dismpaikan oleh Presiden Republik Indonesia. Komunikator akan menampilkan secara berlebihan informasi yang menguntungkan dirinya atau citra yang baik. Sebaliknya akan membuang atau menampilkan dengan jumlah sedikit informasi yang dapat merugiakn citra dan kedudukannya.

Detail merupakan strategi Presiden Republik Indonesia dalam mengekspresikan sikapnya dengan cara implisit. Ketelitian dan keseluruhan dimensi peristiwa, bagian mana diuraikan secara panjang lebar dan bagian mana yang diuraikan sedikit.
Pidato "Kenegaraan di Sidang MPR Tahun 2018" memilki detail yang terdapat pada kutipan berikut.

Saya yakin, jika bangsa Indonesia mau tetap bersatu, berbagi, dan peduli pada sesama anak bangsa, maka Indonesia bukan lagi hanya sekadar nama ataupun gambar sederetan pulau di peta dunia, melainkan menjadi sebuah kekuatan yang disegani oleh bangsabangsa lain di dunia. Saya yakin dengan semangat persatuan, peduli, dan berbagi, ditambah dengan kerja bersama, kita akan mampu menghadapi seluruh tantangan masa depan, mencapai prestasi bangsa: Indonesia maju yang gemilang.

Kutipan dia tas menjelaskan bahwa Indonesia mampu menjadi bangsa yang gemilang dnegan cara saling peduli, berbagi, dan kerja sama mampu mnghadapi tantangan dimasa depan.

Selanjutnya, dalam pidato Presiden Republik Indonesia yang berjudul "Sambutan Penutupan Asian Games 2018 di Hadapan Atlet" memilki detail yang terdapat pada kutipan berikut. 
Ini adalah sebuah lompatan, lompatan besar yang bisa kita jadikan fondasi untuk prestasiprestasi selanjutnya.Karena sebelumnya, saya ngomong apa adanya, sebelumnya kita berada di urutan 17 , sekarang berada di urutan 4, itu juga sebuah lompatan besar. Saya enggak tahu, saya juga enggak mengerti betul. Meskipun saya selalu datang juga di beberapa cabang olahraga untuk melihat kesiapannya seperti apa. Saya lihat, misalnya di pacuan kuda saya lihat, di pencak silat, di skateboard, di voli pantai saya lihat, dan beberapa cabang olahraga lainnya. Saya enggak ngerti betul, atlet ini jurusnya apa? Tapi yang saya pastikan, ini adalah sebuah kerja keras yang luar biasa dari para atlet, para pelatih, para official.

Kutipan di atas menjelaskan bahwa Indonesia sudah mengalami lompatan besar dalam prestasi yang diperoleh oleh para atlet dalam Asian Games. Semua ini berkat kerja keras para panitia penyelengara dan atlet yang telah berupaya memwujudkannya.

1) Praanggapan

Strategi lain yang dapat memberi citra tertentu ketika diterima khalayak merupakan pengertian dari praanggapan.
Elemen ini pada dasarnya digunakan untuk memberi basis rasional, sehingga teks yang disajikan komunikator tampak benar dan menyakinkan.

Praanggapan hadir untuk memberi pernyataan yang dipandang terpecaya dan tidak perlu lagi dipertanyakan kebenarannya karena hadirnya pernyataan tersebut. Praanggapan merupakan fakta yang belum terbukti kebenarannya, tetapi dijadikan dasar untuk mendukung gagasan tertentu.

Pidato Presiden Republik Indonesia "Kenegaraan HUT Ke-72 Proklamasi Kemerdekaan Indonesia" mengungkapkan praanggapan bahwa pemerintah meningkatkan tenaga listrik agar kawasan pinggiran dapat menikmati sarana dan prasarana dengan baik.

Pada pidato "Kenegaraan di Sidang MPR Tahun 2017" Presiden Republik Indonesia menyatakan praaanggapan yang terdapat pada kutipan berikut.

Kita menyadari bahwa keadilan sosial bagi seluruh rakyat Indonesia belum sepenuhnya kita bisa wujudkan. Untuk itu, di tahun ketiga masa bakti Kabinet Kerja ini, Pemerintah lebih fokus untuk melakukan pemerataan ekonomi yang berkeadilan. Kita ingin rakyat-rakyat Indonesia yang berada di pinggiran, di kawasan perbatasan, di pulau-pulau terdepan, di kawasan terisolir 
merasakan hadirnya negara,

merasakan buah pembangunan, dan merasa bangga menjadi

Warga Negara Kesatuan Republik Indonesia.

Pada pernyataan ini merupakan saran yang disampaiakn Presiden Republik Indonesia untuk melakukan pemerataan ekonomi yang berkeadilan terutama bagi kawasan yang terisolir.

Saya yakin, dengan pengalaman yang panjang dalam berdemokrasi, Insya Allah, Pemilu Legislatif dan Pemilu Presiden secara serentak di tahun 2019 akan berlangsung dengan aman, damai, dan demokratis.

Pada kutipan pidato "Kenegaraan HUT Ke-73 Proklamasi Kemerdekaan Indonesia" yang beranggapan bahwa pemilu legislatif dan pemilu presiden berjalan dengan aman, damai dan demokratis.

Pada pidato "Sambutan Penutupan Asian Games 2018 di Hadapan Atlet"menyampaikan praanggapan yang terdapat pada kutipan berikut.

Rakyat berterima kasih kepada Saudara-saudara semuanya. Rakyat menyambut prestasi Saudara-saudara dengan penuh haru dan kebahagiaan. Rakyat menghargai, sangat menghargai pengorbanan dan perjuangan Saudarasaudara. Oleh karena itu, saya tidak rela terhadap mereka yang ada yang mencemooh prestasi Saudara-saudara, dikatakan ini karena kita sebagai tuan rumah jadi diuntungkan. Ya semua yang jadi tuan rumah pasti diuntungkan, semua yang menjadi tuan rumah, bukan hanya kita saja. Tapi kalau enggak ada prestasi, ya kalah. Tuan rumah, siapapun. Saya tidak rela kata-kata seperti itu. Karena saya tahu perjuangan Saudarasaudara semuanya. Saya tahu betul. Sudah kram itu saja masih lari ke sana, lari ke sini.

Presiden Republik Indonesia menganggap bahwa tidak ada yang kalah karena masyarakat menghargai perjuangan para atlet. Masyarakat mengucapakan terimakasih atas prestasi yang kalian torehkan untuk negara Indonesia.

2) Koherensi 
Koherensi adalah jalinan atau pertalian anatr kata, proposisi atau kalimat. Dua buah kalimat atau proposisi yang menggambarkan fakta yang beda dapat dihubungkan dnegan memakai koherensi, sehingga dua fakjta tersebut dapat menjadi berhubungan. Koherensi dapat diamati dan konjungsi yang digunakan (dan, serta, sebelumnya, dan sementara).

Fakta yang tidak berhubungan sekalipun dapat menjadi berhubungan ketika seseorang menghubungkannya. Untuk melihat bagaimana seseorang secara strategis menggunakan wacana untuk mnejelaskan suatu fakta atau peristiwa.

Pidato Presiden Republik Indonesia pada tanggal 16 Agustus 2017, dlam uraiannya menggunakan elemen koherensi. Terdapat pada akutipan berikut.

Dalam tiga tahun terakhir ini, Pemerintah fokus untuk memerangi kemiskinan, menekan ketimpangan, dan mengurangi pengangguran. Hasilnya, tingkat kemiskinan di Indonesia turun, dari 28,59 juta orang pada Maret tahun 2015 menjadi 27,77 juta orang pada Maret tahun 2017. Begitu juga Indeks Rasio Gini Indonesia, yang mengukur tingkat kesenjangan ekonomi, terus membaik dan mencapai 0,393 di bulan Maret 2017, turun dibandingkan dengan angka bulan September 2014 yaitu 0,414.(Widodo:2017:3)

Pemerintah juga sedang menjalankan redistribusi tanah untuk masyarakat dan sudah memberikan 707 ribu hektar kawasan hutan kepada masyarakat adat untuk dikelola secara produktif. Selain itu, juga sedang dijalankan Program Perhutanan Sosial sehingga rakyat di lapisan 40 persen terbawah mendapatkan akses untuk memanfaatkan hutan bagi kesejahteraan mereka.

\section{SIMPULAN dan SARAN}

\section{Simpulan}

Hasil penelitian menunjukkan bahwa strategi yang digunakan Presiden Republik Indonesia terdapat pada elemen tema atau topik. Pemaknaan dalam elemen tema dapat dideteksi dan disimpulkan setelah membaca keseluruhan teks pidato, kemudian mengamati subtema-subtema yang didukung oleh data dan fakta dalam teks pidato tersebut.

Strategi yang digunakan Presiden Republik Indonesia melalui superstruktur terdapat dalam elemen judul, lead, dan story. Pada elemen judul makna ideologi kerakaytan, ideologi sosialisme, dan ideologi nasionalisme dapat dilihat dari pilihan kata yang digunakan untuk menyusun kalimat 
judul dan penempatan kata yang ingin ditonjolkan ataupun ingin disembunyikan pada kalimat judul tersebut. Elemen lead teks pidato Presiden Republik Indonesia dimulai dengan nama dan menyebut judul pidato. Selanjutnya, mulai dengan kutipan langsung dan menjelaskan dengan ringkasan pokok maslah dan dilanjutkan dengan peristiwa atau keadaannya. Strategi untuk menyembunyikan makna pada elemen story dilakukan dengan penempatan pilihan kata yang bermakna sesuai dengan makna yang disampaikan dan dengan membuat uraian yang lebih banyak sesuai dengan maknanya baik pada awal, tengah, maupun akhir wacana.

Strategi yang digunakan Presiden Republik Indonesia untuk menyembunyikan makna ideologi kerakyatan, ideologi sosialisme, dan ideologi nasionalisme dalam struktur mikro terdapat pada elemen latar, detail, kata ganti, bentuk kalimat, praanggapan, koherensi, leksikon dan grafis.

Makna ideologi karakyatan, sosialisme dan nasionalisme biasanya ditunjukkan dengan melampirkan latar, detail, kata ganti, bentuk kalimat, praanggapan, koherensi, leksikon, dan grafis serta uraian yang membuat rakyat agar lebih gemilang, maju, sejahtera, aman dan tentram. Selain itu, makana ideologi sosiallisme ditunjukakan dengan menguraikan kalimat agar rakyat saling menghargai dan menghormati. Makna ideologi nasionalisme meruapakan kalimat dnegan harapan agar rakyat menjadi jujur, adil dan sportifitas, serta menuju masa depan yang gemilang.

Berdasarkan hasil penelitian terhadapa wacana pidato Presiden Republik Indonesia ditemukan ideologi kerakyatan, sosialisme, dan nasionalisme. Ideologi kerakyatan terlihat dari setiap pidato yang disampaikannya yaitu ingin membuat rakyat lebih gemilang, maju, sejahtera, aman dan tentram. Ideologi sosialisme yaitu ingin mempersatukan semua masyarakat yang ada di Indonesia agar saling mengahargai dan menghormati satu sma lain. Ideologi nasionalisme yang ingin selalu membuat rakyat menjadi jujur, maju adil dan aman serta menuju masa depan yang gemilang.

\section{Saran}

Berdasarkan temuan, pembahsan dan simpulan penelitian terhadap pidato Presiden Republik Indonesia, dapat peneliti sampaikan saran-saransebagai berikut.

1. Penelitian ini lebih difokuskan pada analisis teks baik dalam strukturtur makro, superstruktur amupun struktur mikro, oleh karena itu, kepada berbagai pihak yang ingin melakuakan penelitian yang berkaitan dnegan analisis wacana kritis, hendaknya dapat mengembangkan lebih lanjut dengan memperluas aspek yang diteliti.

2. Penelitian ini merupakan analisis wacana kritis terhadap pidato Presiden Republik Indonesia, sehingga merupakan proses berpikir kritis dan upaya bersifat kritis 
terhadap berbagai fenomena rakyat. Oleh karena itu, hasilnya diharapakan dapat digunakan sebagai alternatif bahan pendidikan dan pengajaran bahasa Indonesia, yaitu pembelajaran analisis wacana, khususnya wacana pidato.

\section{DAFTAR PUSTAKA}

Alwi, Hasan. Dan Moeliono, M. Anton. 1999. Tata Bahasa Baku Bahasa Indonesia. Jakarta: Balai Pustaka.

Aminulatif. 2010. "Pemberitaan Sriwijaya FC di Media Massa Palembang: Kajian Analisis Wacana Kritis", Tesis. Palembang: PPs Unsri.

Arikunto, Suharsimi. 2006. Prosedur Penelitian. Jakarta: Rineke Cipta.

Badara, Aris. 2012. Analisis Wacana: Teori, Metode, dan Penerapannya Pada Wacana Media. Jakarta: Kencana.

Darma, Yoce Aliah. 2009. Analisis Wacana Kritis. Bandung: Yrama Widya.

Djajasudarman, T. Fatimah. 2010. Wacana Pemahaman dan Hubungan Antarunsur. Bandung: Aditama.

Eriyanto. 2017. Analisis Wacana: Pengantar Analisis Teks Media. Yogyakarta: LKIS

Fauzan, Umar. 2014. Analisis Wacana Kritis Dari Model Fairclough Hingga Mills.https://scholar.google.co.id/sch olar?

hl=id\&as $\quad \mathrm{sdt}=0 \% 2 \mathrm{C} 5 \& \mathrm{q}=\mathrm{jurnal}+\mathrm{AW}$ K\&btnG=. Di akses 12 Januari 2019.

Gunawan, Puthu. 2013. Analisis Wacana Kritis terhadap Rubrik "Salam Sriwijaya" pada Surat Kabar Sriwijaya Post. Tesis. Palembang: PPs UPGRI.
Idris. 2009. "Analisis Wacana Kritis dalam Artikel Sea Games XXVI 201106-11 pada Surat Kabar Sumatera Ekspres", Tesis. Palembang: PPs UPGRI.

Keraf, Gorys. 1985. Diksi dan Gaya Bahasa. Jakarta: PT Gramedia

Khak, M Abdul. 2015. Formula Kuasa Dalam Bahasa Surat Kabar: Analisis Dimensi Mikro AWK Model Fairclough.

https://scholar.google.co.id/scholar? hl=id\&as sdt=0\%2C5\&q=jurnal+AW K\&btnG=. Di akses 12 Januari 2019.

Purnomo, Mulyadi Eko. "Analisis Wacana Kritis Terhadap media Massa Cetak Terbitan Palembang:, Lingua.Vol 9 No. 1. Unsri Palembang

Rosda. Sudaryat. Yayat. 2011. Makna dalam Wacana. Bandung: CV. Yrama Widya.

Rahmat, Jalaluddin. 2012. Retorika Modern Pendekatan Praktis. Bandung: PT. Remaja Rosda Karya.

Rumpoko, Hadi. 2013. Panduan Pidato dan MC yang memukau. Yogyakarta: Smart Pustaka.

Sobur, Alex. 2002. Analisis Teks Media. Bandung: Alfabeta.

Sugiyono. 2012. Metode Penelitian Pendidikan. Bandung: Alfabeta.

Tim Penyusun. 1994. Kamus Umum Besar Bahasa Indonesia. Jakarta: Balai Pustaka.

Tarigan, Henry G. 2009. Pengajaran Wacana. Bandung: Angkasa. 